\title{
KORELASI ANTARA PENGUASAAN KOSAKATA, MINAT BACA, DAN KEMAMPUAN MERESEPSI CERPEN SUFISTIK: \\ Survei Pada Siswa Madrasah Tsanawiyah Kampung Jawa Tondano Minahasa
}

\author{
Kinayati Djojosuroto \\ FBS Universitas Negeri Manado \\ Jalan Tondano, Sulawesi Utara 95618, Indonesia \\ email: djkinayati@gmail.com
}

\begin{abstract}
At Madrasah Tsanawiyah (MTs), literature is a part of Indonesian Letters and Language class. Literature can refine manners, enrich aesthetic experience, and improve the knowledge of students. Literature teaching increases their ability in understanding, enjoying, loving, and appreciating literary work, and also to help their development of psychological aspects towards shaping their character as a whole. Regarding reading interest, students were helped in understanding and comprehending sufi short story when they mastered the adequate vocabulary. The sufi short story as a work of literature is rich of life values, either local or spiritual ones. Sufi value belongs to spiritual value assessed to develop a person's spiritual state. This study used the survey method with correlation technique. The respondents were tested on vocabulary mastery, given quiz for reading interest, and also taken essay test for the ability to comprehend sufi short story. It was done in MTs Kampung Jawa, Tondano, Minahasa. Based on the analysis of the hypothesis test, all of the alternative hypothesizes (H1) given in this research were accepted. This means that the ability to comprehend sufi short story $(Y)$ can be improved by developing the mastery of vocabulary (X1) and reading interest $(\mathrm{X} 2)$.
\end{abstract}


Di Madrasah Tsanawiyah (MTs), sastra merupakan bagian dari pelajaran Bahasa dan Sastra Indonesia. Sastra dapat memperhalus budi pekerti, memperkaya pengalaman estetik, dan meningkatkan pengetahuan siswa. Pengajaran sastra bertujuan untuk meningkatkan kemampuan siswa dalam memahami, menikmati, mencintai, dan menghargai karya sastra, serta membantu perkembangan aspekaspek kejiwaan anak menuju terbentuknya kebulatan pribadinya. Sehubungan dengan minat baca, siswa sangat terbantu dalam memahami dan meresepsi cerpen sufistik ketika mereka menguasai kosakata yang memadai. Cerpen sufistik sebagai karya sastra, kaya akan nilai-nilai kehidupan, baik itu nilai budaya maupun nilai spiritual. Nilai sufistik termasuk dalam nilai spiritual yang apabila dikaji akan membantu mengembangkan spiritual seseorang. Penelitian ini menggunakan metode survei dengan teknik korelasi. Responden diuji dengan tes penguasaan kosakata, kuis untuk minat baca, dan tes esai untuk kemampuan meresepsi cerpen sufistik. Penelitian ini dilaksanakan di MTs Kampung Jawa Tondano, Minahasa. Berdasarkan analisis pengujian hipotesis, dapat disimpulkan bahwa semua hipotesis alternatif (H1) yang diajukan pada penelitian ini diterima. Hal ini berarti bahwa kemampuan meresepsi cerpen sufistik (Y) dapat meningkat dengan meningkatkan penguasaan kosakata (X1) dan minat baca (X2).

Keywords: correlation, vocabulary, reading interest, comprehension, sufi short story

\section{Pendahuluan}

Sastra merupakan salah satu media penyampaian ide, gagasan, dan pikiran pengarang tentang kehidupan manusia yang dituangkan dalam bentuk tulisan. Sastra dapat berupa prosa, puisi, dan drama. Dari waktu ke waktu sastra berkembang sesuai dengan perkembangan masyarakat, baik dari ragam bentuk maupun tema cerita. Sastra sebagai karya seni tidak hanya mengandung unsur budaya tetapi juga mengandung unsur religi, moral, pengetahuan, penalaran, dan kreativitas dalam kehidupan.

Peristiwa-peristiwa yang terjadi dalam kehidupan manusia merupakan sumber karya sastra. Dengan menggali sumber karya sastra kemudian diangkat dan diungkapkan melalui daya imajinasi yang berupa penafsiran dan perenungan, maka karya sastra yang tercipta akan bernilai tinggi. Seorang pengarang dalam menuangkan idenya menjadi sebuah karya sastra memiliki cara tersendiri. Pengekspresian pengalaman, keadaan, ide, peristiwa, serta nilai-nilai disampaikan pengarang melalui kehidupan tokoh cerita. Dengan memahami kehidupan tokoh cerita, diharapkan pembaca dapat menafsirkan karya sastra dengan tepat, sehingga pembaca mendapat kepuasan batin. Dengan demikian, kreativitas pengarang akan mempengaruhi pembaca dalam menggauli dunia sastra. 
Dengan membaca, siswa akan sering menemukan sejumlah informasi yang membuatnya lebih tahu. Dari hasil membaca, siswa juga terlatih untuk menghubungkan beragam konsep sehingga menjadi rangkaian konsep yang mempunyai arti bagi dirinya, yang pada akhirnya menambah kekayaan informasi yang sudah dimilikinya. Penambahan informasi ini banyak dilakukan dengan membaca berbagai media yang sesuai dengan minat dan kebutuhannya. Dari titik ini, kemudian timbul minat baca seorang siswa agar memperoleh informasi untuk kepentingan kehidupannya.

Selain minat baca, penguasaan kosakata juga menjadi hal penting dalam mencapai penguasaan bahasa. Semakin banyak kosakata yang dimiliki, maka semakin banyak pula ide dan gagasan yang dikuasai. Penguasaan kosakata merupakan ukuran pemahaman seseorang terhadap kosakata suatu bahasa dan kemampuannya dalam menggunakan kosakata tersebut baik secara lisan maupun tertulis. Penguasaan kosakata merupakan bagian dari penguasaan bahasa, sebab jika seseorang menguasai bahasa berarti orang tersebut menguasai kosakata. Penguasaan kosakata yang ada pada diri seseorang dimulai sejak masih bayi dan ketika mampu merespon kata yang diucapkan orang lain.

Sehubungan dengan minat baca, seorang siswa sangat terbantu dalam memahami isi cerpen sufistik, bahkan dapat meresepsinya ketika siswa menguasai kosakata yang memadai. Cerpen sufistik sebagai karya sastra kaya akan nilai-nilai kehidupan, baik itu nilai budaya maupun nilai spiritual. Nilai sufistik termasuk dalam nilai spiritual yang apabila dikaji akan membantu mengembangkan spiritual seseorang. Sebuah cerpen yang mengandung nilai sufistik dalam penceritaannya menggambarkan kehidupan tokoh cerita yang bercirikan sikap hidup seorang sufi. Seorang pengarang akan menyampaikan pesan tentang nilai sufistik tersebut melalui perbuatan, tingkah laku, ucapan, pikiran, dan peristiwa-peristiwa yang dialami tokoh cerita yang menyiratkan kesufian seseorang.

\section{Hakikat Penguasaan Kosakata}

Kosakata (vocabulary) adalah himpunan kata yang diketahui oleh seseorang atau entitas lain, atau merupakan bagian dari suatu bahasa tertentu. Kosakata seseorang didefinisikan sebagai himpunan semua kata-kata yang dimengerti oleh orang tersebut atau semua kata-kata yang kemungkinan akan digunakan oleh orang tersebut untuk menyusun kalimat baru. Kekayaan kosakata seseorang secara umum dianggap merupakan gambaran dari intelegensia atau tingkat pendidikannya. 
Kosakata merupakan salah satu aspek bahasa yang sangat penting keberadaannya. Dalam Kamus Besar Bahasa Indonesia (Dekdikbud, 1996: 527), kosakata diartikan sebagai perbendaharaan kata. Penambahan kosakata seseorang secara umum dianggap merupakan bagian penting, baik dari proses pembelajaran suatu bahasa ataupun pengembangan kemampuan seseorang dalam suatu bahasa yang sudah dikuasai. Murid sekolah sering diajarkan katakata baru sebagai bagian dari mata pelajaran tertentu dan banyak pula orang dewasa yang menganggap pembentukan kosakata sebagai suatu kegiatan yang menarik dan edukatif. Kosakata merupakan keseluruhan kata yang terdapat dalam suatu bahasa, baik kosakata aktif yang digunakan oleh pembaca dan penulis maupun kosakata pasif yang digunakan oleh pembaca dan pendengar, atau kosakata adalah semua kata yang terdapat dalam suatu bahasa atau kata yang dikuasai oleh seseorang atau kata-kata yang dipakai oleh segolongan orang dalam lingkungan yang sama.

Dari dua pengertian di atas dapat dilihat apa sebenarnya yang dimaksud dengan kosakata. Untuk menyusun sebuah kosakata yang benar, maka tidak sembarang kalimat dapat kita rangkai, namun tentunya harus memperhatikan tatanan bahasa agar menjadi susunan kosakata yang benar dan memiliki arti.

Tidak dapat disangkal bahwa penguasaan kosakata adalah bagian yang sangat penting dalam kegiatan pemahaman bacaan, karena manfaat dari kemampuan yang diperolehnya itu akan lahir dalam bentuk penguasaan terhadap pengertian-pengertian yang tepat dan bermakna. Oleh karena itu kata sering dianggap sebagai salah satu satuan dasar semantik. Ada beberapa kata yang memiliki makna yang jelas sedangkan makna yang lain memiliki makna yang kurang jelas.

Berdasarkan paparan teori yang dikemukakan di atas maka dapat disimpulkan bahwa kosakata adalah kata atau kelompok kata yang mempunyai makna tertentu yang digunakan oleh seseorang yang digunakan dalam komunikasi. Sedangkan yang dimaksud dengan penguasaan kosakata dalam penelitian ini adalah kemampuan siswa dalam memahami kosakata dalam cerpen sufistik yang dikuasai siswa secara tepat dan benar.

\section{Hakikat Minat Baca}

Pengertian minat baca antara satu ahli dengan ahli lain selalu berbeda karena perbedaan sudut pandang dan penekanan makna sesuai dengan konteksnya. Minat baca dimaknai sebagai suatu sikap mencurahkan perhatian akan sikap ingin tahu yang intelektual dan bijaksana, serta ditambah dengan suatu usaha 
yang konstan untuk menggali bidang-bidang pengetahuan (informasi) baru, dan adanya kesediaan untuk menyediakan waktu guna melakukan kegiatan tersebut (Tarigan, 1995: 102-103). Dalam pengertian ini sudah terkandung makna bahwa membaca pada dasarnya serupa dengan mencari tambahan pengetahuan baru melalui penginterpretasian lambang-lambang bacaan.

Minat baca merupakan wujud kecenderungan jiwa yang dapat membuat seseorang menjadi senang dan tertarik terhadap bahan bacaan yang dipilihnya. Minat baca juga didefinisikan sebagai kecenderungan jiwa yang diperoleh secara bertahap untuk merespon secara bertahap untuk merespon secara selektif, positif, dan disertai dengan rasa puas terhadap hal-hal khusus yang dibaca (Tingkers, 1995: 309). Berkaitan dengan hal tersebut, pada masa sekarang dan akan datang, kegiatan membaca harus digalakkan sejalan dengan pesatnya perkembangan pendidikan itu sendiri. Ia menambahkan, salah satu cara untuk mencerdaskan kehidupan bangsa adalah membaca. Karena media bacaan yang tersedia tidak akan berarti apabila tidak dibaca. Minat baca juga berperan sebagai motivating force yaitu sebagai kekuatan yang akan mendorong mahasiswa untuk belajar (David, 1994: 99). Selanjutnya, minat baca seseorang dapat dirinci berdasarkan tiga rangsangan dasar, yaitu: 1) minat baca adalah keinginan untuk menangkap dan menghayati apa yang dijumpai di dalam bacaan tersebut; 2) minat baca berasal dari hasrat untuk mengatasi atau setidaknya melonggarkan keterikatan manusia, hal ini berarti kegiatan membaca dengan motif ini hanyalah dilakukan untuk mengisi waktu, melupakan sesuatu, menghibur dan mengganti sesutu yang hidup; dan 3) minat baca adalah mencari keteraturan dan bentuk, mencari apa arti dan makna kehidupan manusia (Franz and Meier, 1996: 8)

Ada istilah konsep minat baca, minat ini sering disebut juga sebagai interest. Minat merupakan gambaran sifat dan sikap ingin memiliki kecenderungan tertentu. Minat juga diartikan kecenderungan hati yang tinggi terhadap sesuatu dan keinginan yang kuat untuk melakukan sesuatu. Minat bukan bawaan dari lahir, melainkan dapat dipengaruhi oleh bakat. Minat diciptakan atau dibina agar tumbuh dan terasa. Dalam pengertian umum minat berarti ketertarikan kepada sesuatu. Minat adalah kesadaran seseorang terhadap suatu objek, orang, atau suatu hal, atau suatu situasi yang terpaut dengan dirinya (Whiterington, 2000: 135).

Berdasarkan pendapat-pendapat di atas, dapat disimpulkan bahwa minat baca merupakan proses aktivitas komunikasi yang kompleks yang bertujuan untuk melihat, memahami isi atau makna, dan memperoleh pesan 
yang hendak disampaikan penulis melalui media kata-kata atau bahasa tulis sehingga diperoleh pemahaman terhadap bacaan. Seseorang yang memiliki minat baca akan memperoleh informasi dan pengetahuan yang berguna bagi kehidupannya.

Dapat disimpulkan bahwa hakikat minat baca adalah kecenderungan jiwa yang diperoleh secara bertahap utntuk merespon secara selektif, positif, dan disertai dengan rasa puas terhadap hal-hal khusus terhadap bacaan. Jadi minat baca adalah suatu kecenderungan jiwa yang diperoleh dengan cara bertahap untuk merespon kegiatan secara selektif dan positif, yang membuat seseorang menjadi tertarik dan merasa puas terhadap bacaan yang dipilihnya.

\section{Pengertian Cerpen}

Cerpen adalah singkatan dari cerita pendek, disebut demikian karena jumlah halamannya yang sedikit, situasi, dan tokoh ceritanya juga digambarkan secara terbatas (Tarigan, 1996: 276). Cerpen dalam bahasa Inggris disebut short story, dalam bahasa Perancis disebut nouvelle atau conte, dan dalam bahasa Jerman disebut kurzgeschichte. Lebih dikenal lazim disebut dengan cerpen, yaitu cerita rekaan yang memusatkan diri pada satu tokoh dalam satu situasi pada satu saat hinggamemberikan kesan tunggal terhadap pertikaian yang mendasari cerita tersebut.

Mengutip Edgar Allan Poe (Jassin 1991: 72), cerpen adalah sebuah cerita yang selesai dibaca dalam sekali duduk, kira-kira berkisar antara setengah sampai dua jam (Nurgiyantoro, 2000: 72). Semi mengemukakan bahwa cerpen adalah karya sastra yang memuat penceritaan secara memusat kepada suatu peristiwa pokok saja. Semua peristiwa lain yang diceritakan dalam sebuah cerpen, tanpa kecuali ditujukan untuk mendukung peristiwa pokok. Dalam kesingkatannya itu cerpen akan dapat menampakkan pertumbuhan psikologis para tokoh ceritanya, hal ini berkat perkembangan alur ceritanya sendiri. Ini berarti, cerpen merupakan bentuk ekspresi yang dipilih dengan sadar oleh para sastrawan penulisnya (Semi, 1993: 34).

\section{Unsur-Unsur Intrinsik Cerpen \\ 1. Tema}

Tema adalah gagasan inti. Dalam sebuah cerpen, tema bisa disamakan dengan pondasi sebuah bangunan. Tidak mungkin mendirikan sebuah bangunan tanpa pondasi. Dengan kata lain tema adalah sebuah ide pokok, pikiran utama sebuah cerpen, pesan, atau amanat. Tema juga menjadi dasar 
tolak untuk membentuk rangkaian cerita dan dasar tolak untuk bercerita. Tidak mungkin sebuah cerita tidak mempunyai ide pokok. Tema adalah sesuatu yang hendak disampaikan pengarang kepada para pembacanya. Sesuatu itu biasanya adalah masalah kehidupan, komentar pengarang mengenai kehidupan, atau pandangan hidup si pengarang dalam menempuh kehidupan luas ini.

\section{Alur atau Plot}

Alur adalah rangkaian peristiwa yang menggerakkan cerita untuk mencapai efek tertentu. Banyak anggapan keliru mengenai plot. Plot seringkali dimaknai sebagai jalan cerita. Dalam pengertian umum, plot adalah suatu permufakatan atau rancangan rahasia guna mencapai tujuan tertentu. Plot adalah semua aktivitas untuk mencapai yang diinginkan, bukan sekadar rancangan tentang tujuan. Semua peristiwa yang terjadi di dalam cerita pendek harus berdasarkan hukum sebab-akibat, sehingga plot bukan mengacu pada jalan cerita, namun menghubungkan semua peristiwa.

\section{Tokoh dan Penokohan}

Cerita tanpa tokoh mustahil ada dan tanpa cerita tidak akan ada karya sastra. Tokoh cerita bisa dibedakan berdasarkan peranannya, yakni tokoh utama, tokoh pembantu, dan tokoh tambahan. Tokoh utama adalah tokoh yang memegang peranan penting dalam cerita. Mereka menjadi pendukung tema utama dalam cerita. Berdasarkan watak yang diperankan, tokoh utama dapat dibedakan menjadi tokoh protagonis (tokoh baik), tokoh antagonis (tokoh jahat), tokoh wirawan/wirawati (tokoh baik pendukung tokoh protagonis), dan tokoh antiwirawan/antiwirawati (tokoh jahat pendukung tokoh antagonis). Dalam kasus di mana tokoh utamanya lebih dari satu orang maka tokoh yang lebih penting disebut tokoh inti (tokoh pusat). Para tokoh tersebut, terutama tokoh protagonis dan tokoh antagonis, harus digambarkan sebagai tokoh dengan profil yang utuh. Tokoh utama harus digambarkan sebagai tokoh yang hidup, tokoh yang utuh, bukan tokoh mati yang sekadar menjadi boneka mainan di tangan pengarangnya. Tokoh cerita harus digambarkan sebagai tokoh yang memiliki kepribadian, berwatak, dan memiliki sifat-sifat tertentu. Penokohan adalah penciptaan citra tokoh dalam cerita. Tokoh harus tampak hidup dan nyata hingga pembaca merasakan kehadirannya. Dalam cerpen modern, berhasil tidaknya sebuah cerpen ditentukan oleh berhasil tidaknya menciptakan citra, watak, dan karakter tokoh. Penokohan, yang di dalamnya ada perwatakan sangat penting bagi sebuah cerita. Bisa dikatakan ia sebagai mata air kekuatan sebuah cerita pendek (Tarigan, 1995:21). 


\section{Latar (Setting)}

Latar (setting) adalah segala keterangan mengenai waktu, ruang, dan suasana dalam suatu cerita. Pada dasarnya, latar mutlak dibutuhkan untuk menggarap tema dan plot cerita, karena latar harus bersatu dengan teman dan plot untuk menghasilkan cerita pendek yang gempal, padat, dan berkualitas. Kalau latar bisa dipindahkan ke mana saja, berarti latar netral.

\section{Sudut Pandang Tokoh (Point of View)}

Di antara elemen yang tidak bisa ditinggalkan dalam membangun cerita pendek adalah pandangan tokoh yang dibangun sang pengarang. Sudut pandang tokoh ini merupakan visi pengarang yang dijelmakan ke dalam pandang tokoh-tokoh bercerita. Jadi sudut pandang ini sangat erat dengan teknik bercerita. Sudut pandang ini ada beberapa jenis, tetapi yang umum adalah:

Sudut pandang orang pertama, lazim disebut point of view orang pertama. Pengarang menggunakan sudut pandang "aku" atau "saya". Di sini yang harus diperhatikan adalah pengarang harus netral dengan "aku" dan "saya".

Sudut pandang orang ketiga, biasanya pengarang menggunakan tokoh "ia", atau "dia". Atau bisa juga dengan menyebut nama tokohnya; "Ina”, "Ino", dan "Asty", misalnya.

Sudut pandang campuran, di mana pengarang membaurkan antara pendapat pengarang dan tokoh-tokohnya. Seluruh kejadian dan aktivitas tokoh diberi komentar dan tafsiran, sehingga pembaca mendapat gambaran mengenai tokoh dan kejadian yang diceritakan.

Sudut pandangan yang berkuasa. Teknik ini menggunakan kekuasaan si pengarang untuk menceritakan sesuatu sebagai pencipta. Sudut pandangan yang berkuasa ini membuat cerita sangat informatif. Sudut pandang ini lebih cocok untuk cerita-cerita bertendens.

\section{Unsur Ekstrinsik Cerpen}

Para kritikus sastra saling berbeda-beda dalam menetapkan unsur-unsur apa saja yang termasuk dalam lingkup struktur ekstrinsik karya sastra berbentuk prosa fiksi. Struktur ekstrinsik mencakup faktor sosial-ekonomi, faktor kebudayaan, faktor sosio-politik, keagamaan, dan tata nilai yang dianut dalam masyarakat (Semi, 1993:35). Unsur-unsur yang termasuk dalam lingkup struktur ekstrinsik ini antara lain: (1) keadaan subjektifitas individu pengarang (seperti: sikap, keyakinan, dan pandangan hidup); (2) psikologi, meliputi psikologi pengarang, psikologi pembaca, dan psikologi terapan; (3) keadaan lingkungan di sekitar pengarang (seperti: 
politik, ekonomi, dan sosial); (4) Pandangan hidup suatu bangsa (ideologi); dan (5) Karya sastra atau karya seni lainnya (Nurgiyantoro, 2000: 24).

\section{Pengertian Cerpen Sufistik}

Kata sufisme (sufism) lahir di Banghdad dan merupakan penanda kebangkitan gerakan kebatinan sebagai respon terhadap cara hidup para pejabat dan elit politik Daulah Abasiyah yang telah dimulai sejak Daulah Umayah di Damaskus (Suara Merdeka, 6 Oktober 2011). Institusi-institusi yang mencirikan sufi baru mulai memainkan peran penting dalam sejarah Islam pada sekitar abad XII. Kaum sufi yang ada pada masa ini merupakan kaum elit masyarakat dan sering memimpin gerakan pembaruan, atau perlawanan terhadap penindasan dan dominasi asing atau kolonial. Di pertengahan abad kedua puluh cukup banyak masyarakat dan gerakan sufi muncul di Eropa dan Amerika Utara (Esposito, 1998: 207).

Tasawuf menyangkut masalah rohani dan batin manusia yang tak dapat dilihat, maka ia amat sulit didefinisikan. Tasawuf dapat dipahami, tetapi bukan dalam bentuk hakikatnya, melainkan dalam bentuk gejala-gejala yang tampak dalam ucapan, cara, dan sikap hidup para sufi. Meskipun demikian, para ahli tasawuf tetap membuat definisi tasawuf sesuai dengan pengalaman empirik masing-masing dalam mengamalkan tasawuf. Namun, para pakar sepakat bahwa tasawuf (sufisme) khusus bagi Islam.

Sufisme berasal dari kata shaff yang memiliki makna asli 'seseorang yang berbusana wol. Secara bertahap istilah ini menunjukkan suatu kelompok yang membedakan diri dari mereka yang lain dengan cara menekankan ajaranajaran dan praktik-praktik khusus tertentu dari al Qur'an dan Sunnah. Pada abad kesembilan, tashawwuf secara harfiah berarti 'menjadi sufi' (Esposito, 1998: 207)

\section{Berikut Beberapa Pengertian Tentang Tasawuf Menurut Abu Su'ud:}

Pertama, tasawuf berasal dari kata saff atau barisan dalam shalat. Pengikut tasawuf mempunyai iman yang kuat, jiwa yang bersih, dan selalu memilih saff paling depan. Kedua, berasal dari kata saufanah, sejenis buah-buahan kecil berbulu yang tumbuh di gurun pasir Arab. Kaum sufi bagaikan buah tersebut, yaitu mengenakan pakaian berbulu, hidup dalam kegersangan fisik, tetapi subur batinnya. Ketiga, berasal dari kata suffah yang berarti kamar di pinggiran Masjid Nabawi, untuk tinggal para sahabat Nabi yang Miskin. Mereka disebut ahlus sufa, yang mempunyai sifat-sifat teguh pendirian, takwa, 
zuhud, dan tekun beribadah. Keempat, tasawuf merujuk pada kata safwah yang berarti sesuatu yang terpilih atau terbaik. Kelima, dirujuk dari kata safa atau sarty yang berarti bersih atau suci. Maksudnya, kehidupan seorang sufi diarahkan pada penyucian batin untuk taqarrub pada Allah. Keenam, berasal dari kata theosofhi (bahasa Yunani). Theo berarti Tuhan, sophos dapat dimaknai sebagai hikmat, jadi theosofhi berarti hikmat ketuhanan (Suara Merdeka, 06 Oktober 2001).

Definisi di atas, dapat ditarik kesimpulan bahwa tasawuf merupakan kehidupan seorang sufi yang memiliki iman yang kuat, jiwa yang bersih, bertakwa, dan zuhud yang senantiasa taqarrub kepada Allah sehingga subur batinnya dan menjadikannya terpilih. Tasawuf ini didasarkan pada hikmat ketuhanan. Senada dengan pengertian kelima yang diberikan Abu Su'ud, Harun Nasution berpendapat bahwa tasawuf berarti berusaha mendekatkan diri kepada Allah sedekat-dekatnya (Nasution, 1999: 10). Hal ini menunjukkan bahwa selain untuk memperbaiki akhlak, tasawuf sekaligus digunakan sebagai cara taqarrub kepada Allah (http://www.klikdt.com).

\section{Nilai Sufistik dalam Cerpen}

Cerpen sufistik sebagai karya sastra, kaya akan nilai-nilai kehidupan, baik itu nilai budaya maupun nilai spiritual/religius. Nilai sufistik termasuk dalam nilai spiritual yang apabila dikaji akan membantu mengembangkan spiritualitas seseorang.

Sebuah cerpen yang mengandung nilai sufistik, dalam penceritaannya tergambarkan kehidupan tokoh cerita yang bercirikan sikap hidup seorang sufi. Seorang pengarang akan menyampaikan pesan tentang nilai sufistik tersebut melalui perbuatan, tingkah laku, ucapan, pikiran, dan peristiwa-peristiwa yang dialami tokoh cerita yang menyiratkan kesufian seseorang.

Cerpen sufistik sebagai karya seni yang kaya akan nilai keagamaan (religius), budaya, moral, pengetahuan, kreativas tentang kehidupan, apabila dikaji akan mendatangkan banyak manfaat. Dengan memahami dan menghayati cerpen sufistik secara utuh, akan memberikan pengalaman baru bagi siswa. Selain itu cerpen sufistik dapat memperhalus budi pekerti, memperkaya pengalaman religius, estetik, memperkaya jiwa, dan menimbulkan kepekaan terhadap nilainilai yang ada dalam kehidupan, sehingga akan terbentuk pribadi dan watak siswa yang utuh. Dengan demikian, cerpen sufistik sebagai karya sastra perlu diajarkan kepada siswa melalui apresiasi karya sastra.

Dapat disimpulkan bahwa cerpen sufistik adalah cerpen yang berisi 
nilai-nilai ilmu tasawuf, menggambarkan tingkah laku manusia yang bersifat amalan terpuji maupun tercela, agar hatinya menjadi benar dan lurus dalam menuju jalan ke Allah SWT sehingga ia dekat sedekat-dekatnya di hadiratNya. Cerpen sufistik menggambarkan tentang segala sesuatu yang berkenaan dengan perbuatan manusia yang sesuai dengan ilmu tasawuf. Hal ini ditujukan agar setiap orang menjauhkan diri dari hal-hal yang terlarang agar ia dekat dengan Allah SWT.

\section{Metodologi Penelitian}

\section{A. Tujuan Penelitian}

Secara khusus penelitian ini bertujuan untuk mengetahui korelasi antara: (1) penguasaan kosakata (X1), minat baca(X2), dan kemampuan meresepsi cerpen sufistik (Y).

\section{B. Tempat dan Waktu Penelitian}

Penelitian ini dilaksanakan di Madrasah Tsanawiyah Kampung Jawa Tondano, pada kelas IX semester 2 tahun 2014.

\section{Metode Penelitian}

Penelitian ini menggunakan metode survei dengan teknik korelasional. Dalam penelitian ini, responden tidak dikenakan perlakuan apapun akan tetapi hanya diberikan tes untuk memperoleh skor atau nilai penguasaan kosakata, kuis untuk minat baca dan tes esai untuk kemampuan meresepsi cerpen sufistik. Dengan demikian, nilai yang dianalisis dalam penelitian ini hanya menggambarkan apa yang telah dimiliki siswa.

Teknik yang digunakan dalam penelitian ini adalah teknik analisis korelasional, yaitu teknik yang dirancang untuk mengetahui seberapa besar hubungan variabel bebas dengan variabel terikat. Secara korelasional, penelitian ini berupaya mencari hubungan penguasan kosakata, minat baca, dan kemampuan meresepsi cerpen sufistik. Dari hubungan tersebut akan dianalisis lebih lanjut untuk mencari besarnya hubungan dari tiap-tiap variabel bebas yaitu X1 dan X2 terhadap variabel terikat yaitu Y.

\section{Variabel Penelitian}

Penelitian ini memiliki 2 (dua) variabel bebas dan 1 (satu) variabel terikat. Variabel bebas yang pertama adalah penguasaan kosakata (X1), minat baca (X2), dan kemampuan meresepsi cerpen sufistik (Y) sebagai variabel terikat.

Konstelasi penelitian dapat digambarkan sebagai berikut: 


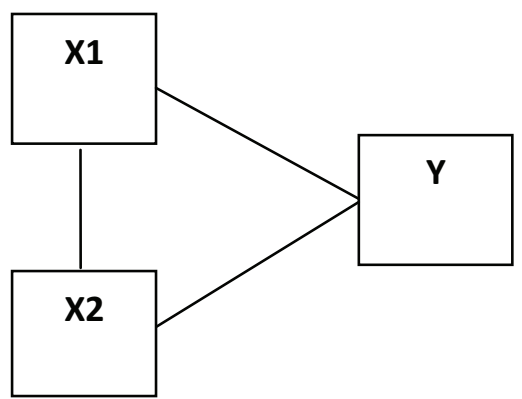

\section{E. Pengajuan Hipotesis Penelitian}

1. Terdapat hubungan positif antara penguasaan kosakata dan kemampuan meresepsi cerpen sufistik

2. Terdapat hubungan positif antara minat baca dan kemampuan meresepsi cerpen sufistik

3. Terdapat hubungan positif antara penguasaan kosakata, minat baca, dan kemampuan meresepsi cerpen sufistik.

Hipotesis Statistik

Hipotesis pertama : Ho $\quad: p_{\gamma} 1=0$

H1 $: \mathrm{p}_{\gamma} 1>_{\mathrm{O}}$

Hipotesis kedua : Ho : $\mathrm{p}_{\gamma} 2=0$

H1 : $\mathrm{p}_{\gamma} 2>\mathrm{O}$

Hipotesis ketiga $\quad: \quad$ Ho $: \mathrm{p}_{\gamma} \cdot 12=\mathrm{o}$

$\mathrm{H} 1 \quad: \mathrm{p}_{\gamma} \cdot 12>\mathrm{o}$

Keterangan

pr1 = koefisien korelasi penguasaan kosakata (X1) dengan kemampuan meresepsi cerpen sufistik.

pr2 = koefisien korelasi (X2) minat baca dengan kemampuan meresepsi cerpen sufistik

pr.12 = koefisien korelasi penguasaan kosakata dan minat baca dengan kemampuan meresepsi cerpen sufistik.

\section{F. Teknik Pengumpulan Data}

Pengumpulan data dalam penelitian ini akan menggunakan tes untuk pengumpulan data penguasaan kosakata (variabel X1), kuisioner/angket untuk variabel minat baca (variabel X2), dan tes untuk pengumpulan data kemampuan meresepsi cerpen sufistik (variabel Y). Lembaran tes berisikan petunjuk pengerjaan soal pertanyaan yang akan dijawab siswa, dengan harapan siswa menjawab sesuai dengan tuntutan soal. Datanya berupa nilai yang 
diperoleh dari hasil jawaban siswa.

Adapun pengembangan instrumen ditempuh melalui beberapa langkah, yaitu: (1) menyusun indikator setiap variabel berdasarkan teori pada setiap variabel; (2) menyusun kisi-kisi instrumen masing-masing variabel; (3) menyusun butir-butir soal dan penetapan skala pengukurannya; (4) melakukan uji coba instrumen, dan (5) melakukan uji coba validasi dan reabilitas instumen penelitian.

Pada penelitian ini terdapat satu variabel terikat yaitu kemampuan meresepsi cerpen sufistik (Y) dan dua variabel bebas yaitu penguasaan kosakata (X1), dan minat baca (X2). Berdasarkan kajian teori yang telah dikemukakan di atas, maka secara konseptual dan operasional variabel-variabel penelitian dapat dituliskan sebagai berikut:

\section{G. Instrumen Tes kemampuan Meresepsi Cerpen Sufistik}

Tes Meresepsi Cerpen Sufistik dikembangkan dari cerpen sufistik yang berjudul "Sepotong Kayu untuk Tuhan" karya Kuntowijoyo. Tes kemampuan meresepsi cerpen terdiri dari 10 soal esai dan dikerjakan siswa selama 90 menit. Guna menentukan indikator-indikator tes kemampuan meresepsi cerpen sufistik dikembangkan melalui definisi konseptual dan definisi operasional sebagai berikut :

a. Definisi Konseptual

Kemampuan meresepsi cerpen sufistik adalah kesanggupan siswa dalam menangkap informasi atau ide-ide yang disampaikan oleh penulis melalui teks cerpen sufistik, sehingga siswa dapat memahami dan menginterprestasikan ide-ide yang ditemukan, baik makna yang tersurat maupun yang tersirat dari keseluruhan cerpen tersebut.

b. Definisi Operasional

Kemampuan meresepsi cerpen sufistik adalah kesanggupan siswa dalam menangkap informasi atau ide-ide yang disampaikan oleh penulis melalui teks cerpen yang ditunjukkan oleh skor yang mencakup: 1) unsur intrinsik yaitu tema, tokoh dan penokohan, alur, latar, amanat, 2) unsur ekstrinsik yaitu sabar, tawakal, ridha, mahabbah, zuhud, syari'at, ma'rifat, dan syauq.

Untuk mengetahui skor tersebut diberikan tes esai 10 soal untuk variabel Y yaitu kemampuan meresepsi cerpen. Siswa yang memberikan jawaban yang benar akan diberi skor 100. Dengan demikian, jawaban yang benar ini akan mencerminkan kemampuan siswa meresepsi cerpen sufistik. 


\section{H. Populasi dan Sampling}

Populasi dalam penelitian ini adalah siswa Madrasah Tsanawiyah (MTs) Kampung Jawa Tondano Minahasa yang berjumlah 95 orang dalam tahun ajaran 2014/2015. Sedangkan sampel penelitian adalah siswa kelas IX yang berjumlah 35 orang. Kelas IX dijadikan sampel karena kelas ini memenuhi syarat dalam pelaksanaan penelitian ini.

\section{Hasil Penelitian dan Pembahasan}

Dalam bagian ini akan dikemukakan hasil penelitian yang meliputi deskripsi data, pengujian hipotesis, hasil analisis data dan interprestasi, serta keterbatasan penelitian.

\section{Deskripsi Data}

Data ini diperoleh dari sampel yang berjumlah 35 orang siswa. Data penelitian meliputi nilai penguasaan kosakata, nilai tes berupa kuis minat baca, dan nilai tes kemampuan meresepsi cerpen sufistik. Skor hasil tes dihitung berdasarkan rentangan nilai 0-100. Berikut ini diuraikan data penelitian.

Tabel 1. Daftar Kelas Interval Data Penelitian.

\begin{tabular}{|l|l|l|l|}
\hline No & $X 1$ & $X 2$ & $Y$ \\
\hline 1 & $47-54$ & $53-60$ & $50-54$ \\
\hline 2 & $55-62$ & $61-68$ & $55-59$ \\
\hline 3 & $63-70$ & $69-76$ & $60-64$ \\
\hline 4 & $72-78$ & $77-84$ & $65-69$ \\
\hline 5 & $79-86$ & $85-92$ & $70-74$ \\
\hline 6 & $87-94$ & $93-100$ & $75-80$ \\
\hline
\end{tabular}

Sumber: Hasil analisis, 2014

\section{Hasil Tes Penguasaan Kosakata}

Dari data-data yang telah terkumpul dan dianalisis diketahui nilai tertinggi sebesar 93 dan terendah 47. Nilai rata-rata sebesar 72,200. Besar variansi adalah 542,664 dan standar deviasi atau simpangan baku adalah 23,295.

2. Hasil Tes (Kuis) Minat Baca

Dari data-data yang terkumpul dan dianalisis mengenai minat baca diketahui nilai tertinggi sebesar 100 dan nilai terendah sebesar 53. Nilai ratarata sebesar 79,257. Besar variansi adalah 318,384 dan standar deviansi atau 
simpangan baku adalah 17,843.

3. Hasil Tes Kemampuan Meresepsi Cerpen Sufistik

Data yang diperoleh dari tes kemampuan meresensi cerpen sufistik adalah nilai tertinggi sebesar 80 dan nilai terendah sebesar 50. Nilai rata-rata tes kemampuan meresensi cerpen sufistik adalah 63,429. Besar variansi adalah 462, 380 dan besar simpangan baku 21,508.

\section{Pengujian Hipotesis}

Sebelum ketiga variabel dihitung menggunakan rumus korelasi ganda, terlebih dahulu dihitung uji keberartian korelasi sederhana antara dua variabel. Perhitungannya sebagai berikut:

\section{Uji Keberartian Korelasi Sederhana}

Uji keberartian korelasi sederhana menggunakan korelasi Pearson Product Moment, dengan derajat kebebasan 33.

1. Korelasi Penguasaan Kosakata dengan Kemampuan Meresepsi Cerpen Sufistik

Setelah dianalisis, diperoleh koefisien korelasi antara penguasaan kosakata dengan kemampuan meresepsi cerpen sufistik sebesar 0,035. Untuk melihat apakah penguasaan kosakata dengan kemampuan meresepsi cerpen sufistik signifikan atau tidak signifikan pada taraf 0,05, maka setelah dilakukan penghitungan diperoleh nilai to $=0,201$, sedangkan pada tabel menunjukkan nilai ttsebesar 0,349 (r:0,05 dan derajat kebebasan 33). Jadi, t observasi lebih kecil dari pada $\mathrm{t}$ tabel, yaitu : to $=0,201 \mathrm{r} t \mathrm{t}=0,349$.

Hal ini berarti ada hubungan yang signifikan antara penguasaan kosakata dengan kemampuan meresensi cerpen sufistik.

Tabel 2. Tabel Sebaran Korelasi Penguasaan Kosakata dengan Kemampuan Meresensi Cerpen Sufistik (rx1y : 0,035)

\begin{tabular}{|c|c|c|c|c|c|c|c|}
\hline X1 & & & & & & & \\
\hline $87-94$ & & II & III & II & I & & 8 \\
\hline $79-86$ & & I & & & I & II & 4 \\
\hline $71-78$ & & I & II & III & II & I & 9 \\
\hline $63-70$ & I & I & III & I & & & 6 \\
\hline $55-62$ & & I & & & I & II & 4 \\
\hline
\end{tabular}




\begin{tabular}{|c|c|c|c|c|c|c|c|}
\hline $47-54$ & & II & I & I & & & 4 \\
\hline Fx1 & I & 8 & 9 & 7 & 5 & 5 & 35 \\
\hline
\end{tabular}

Sumber: Hasil analisis, 2014

2. Korelasi Minat Baca dengan Kemampuan Meresepsi Cerpen Sufistik

Setelah dianalisis, diperoleh koefisien korelasi antara minat baca dengan kemampuan meresensi cerpen sufistik (rx2y) sebesar 0,589. Untuk melihat apakah minat baca dengan kemampuan meresensi cerpen sufistik signifikan atau tidak signifikan pada taraf 0,05 digunakan rumus tr. Setelah dilakukan perhitungan diperoleh nilai to $=4,187$. Sedang pada tabel menunjukkan nilai $\mathrm{tt}=0,349(\mathrm{dk}=33)$. Jadi, $\mathrm{t}$ observasi lebih besar dari pada $\mathrm{t}$ tabel, yaitu :to $=4,187>\mathrm{tt}=0,349$

Hal ini berarti ada hubungan yang signifikan antara minat baca dengan kemampuan meresensi cerpen sufistik.

Tabel 3. Tabel Sebaran Korelasi Minat Baca dengan Kemampuan Meresepsi Cerpen

Sufistik (rx2y:0,589)

\begin{tabular}{|c|c|c|c|c|c|c|c|}
\hline$X 2$ & $50-54$ & $55-59$ & $60-64$ & $65-69$ & $70-74$ & $75-80$ & fy \\
\hline $93-100$ & & & I & I & & III & 5 \\
\hline $85-92$ & & II & II & I & II & II & 9 \\
\hline $77-84$ & & I & I & IIII & III & & 9 \\
\hline $69-76$ & I & II & I & I & & & 5 \\
\hline $61-68$ & & II & II & & & & 5 \\
\hline $53-60$ & & I & I & & & & 2 \\
\hline Fx2 & I & 8 & 9 & 7 & 5 & 5 & 35 \\
\hline
\end{tabular}

Sumber: Hasil analisis, 2014

3. Uji Keberartian Korelasi Ganda

Berdasarkan penghitungan uji keberartian korelasi ganda, untuk korelasi penguasaan kosakata, minat baca, dan kemampuan meresepsi cerpen sufistik terlebih dahulu dikemukakan harga-harga koefisien korelasi sederhana sebagai berikut: 


\begin{tabular}{|l|l|l|}
\hline Korelasi & Koefisien Korelasi & Signifikan \\
\hline $\begin{array}{l}\text { Penguasaan kosakata dengan } \\
\text { kemampuan meresepsi cerpen } \\
\text { sufistik }\end{array}$ & $r \times 1 y: 0,035$ & $0,201 \square 0,349$ \\
\hline $\begin{array}{l}\text { Minat baca dengan kemampuan } \\
\text { meresepsi cerpen sufistik }\end{array}$ & $r \times 2 y: 0,589$ & $4,187>0,349$ \\
\hline
\end{tabular}

Berdasarkan penghitungan uji keberartian korelasi ganda, untuk korelasi penguasaan kosakata, minat baca, dan kemampuan meresepsi cerpen sufistik diperoleh koefisien korelasi ganda Ry.x1x2 =0,488. Hasil uji signifikan korelasi ganda (F) diperoleh : 5,0013, sedang F tabel sebesar 3,30. Jadi korelasi antara penguasaan kosakata, minat baca, dan kemampuan meresepsi cerpen sufistik adalah signifikan.

\section{Hasil Analisis Data dan Interprestasi}

Berdasarkan uji keberartian korelasi sederhana dan uji keberartian korelasi ganda, di bawah ini dideskripsikan hasil analisis data dan interprestasi.

\section{Hasil Analisis Data}

Berdasarkan data-data yang ada, maka pengujian hipotesis nol dalam penelitian dapat dijawab sebagai berikut :

1. H1 berbunyi, "Ada korelasi yang signifikan antara penguasaan kosakata dan kemampuan meresepsi cerpen sufistik siswa kelas IX MTs Kampung Jawa Tondano" diterima, hal ini teruji dengan rx1y : $0,0201>\mathrm{rt}: 0,349(\gamma: 0,05)$

2. H1 yang berbunyi, "Ada korelasi yang signifikan antara minat baca, dan kemampuan meresepsi cerpen sufistik siswa kelas IX MTs Kampung Jawa Tondano" diterima, hal ini teruji dengan rx2y : 4,187 r rt : 0,349 ( r: 0,05)

3. H1 yang berbunyi, "Ada korelasi antara penguasaan kosakata dan minat baca dengan kemampuan meresepsi cerpen sufistik, siswa kelas IX MTs Kampung Jawa Tondano" diterima, hal ini teruji dengan Ry.x1x2 : 0,488 r Rt : 0,349 r:0,05)

$\mathrm{Fr}$ $: 5,00013$ r $\mathrm{Ft}: 3,30$ 


\section{Interpretasi Hasil Pengujian Hipotesis}

1. Interpretasi meliputi interpretasi hasil korelasi penguasaan kosakata dengan kemampuan meresepsi cerpen sufistik, interpretasi korelasi minat baca dengan kemampuan meresepsi cerpen sufistik.

2. Interpretasi hasil pengujian hipotesis penguasaan kosakata dan kemampuan meresepsi cerpen sufistik.

Hasil pengujian hipotesis nol menyatakan ada hubungan yang signifikan antara penguasaan kosakata dengan kemampuan meresepsi cerpen sufistik, koefisien korelasi sebesar rx1y =0,035. Hasil tersebut menunjukkan bahwa $\mathrm{r}$ observasi lebih kecil daripada $\mathrm{rt}=0,349$ pada taraf $~ 0,05$ dengan $\mathrm{dk}=33$.

Untuk memprediksi seberapa besar sumbangan antara variabel penguasaan kosakata dengan kemampuan meresepsi cerpen sufistik maka hasil r dikuadratkan. Dengan demikian, hasilnya adalah $(0,035) 2=0,01=1 \%$

Dari penghitungan di atas berarti asumsi yang menyatakan adanya hubungan yang signifikan antara penguasaan kosakata dengan kemampuan meresepsi cerpen sufistik terbukti sangat baik. Hal itu berarti, siswa yang penguasaan kosakatanya tinggi tentu kemampuan meresepsi cerpennya juga tinggi.

Hasil penelitian didapatkan bahwa nilai rata-rata penguasaan kosakata adalah 63,429 dan nilai rata-rata untuk kemampuan meresepsi cerpen sufistik adalah 72,200. Nilai kemampuan meresepsi cerpen sufistik tinggi bila dibandingkan dengan nilai penguasaan kosakata. Jadi, siswa yang memiliki penguasaan kosakata tinggi sudah tentu memiliki kemampuan meresepsi cerpen yang baik.

3. Interpretasi Hasil Pengujian Hipotesis Minat Baca dan Kemampuan Meresepsi Cerpen Sufistik.

Hasil pengujian hipotesis nol menyatakan ada korelasi yang signifikan antara minat baca dengan kemampuan meresepsi cerpen sufistik. Koefisien korelasi sebesar $\mathrm{rx} 2 \mathrm{y}=0,589$. Hasil tersebut menunjukkan bahwa $\mathrm{r}$ observasi lebih besar dari pada $\mathrm{rt}=0,349$ pada taraf $=0,05$ dengan derajat kebebasan 33

Untuk meramalkan seberapa besar sumbangan antara variabel minat baca dengan kemampuan meresepsi cerpen sufistik, maka hasil r dikuadratkan. Dengan demikian, hasilnya adalah $(0,589) 2=0,3469=34,698$.

Berdasarkan penghitungan di atas, maka pernyataan yang menyatakan adanya korelasi antara minat baca dengan kemampuan meresepsi cerpen sufistik dapat diterima. Dari hasil penelitian ini dapat diprediksi bahwa 
siswa yang memiliki minat baca tinggi akan memiliki kemampuan meresepsi cerpen sufistik yang tinggi pula. Hal ini disebabkan siswa selalu punya minat baca yang merupakan petunjuk langkah-langkah kerja setiap siswa yang akan melakanakan resepsi atau pembelajaran lain.

Hasil penelitian menunjukkan nilai rata-rata untuk minat baca adalah 63,429 dan nilai rata-rata kemampuan meresepsi cerpen sufistik adalah 79,257 . Nilai kemampuan meresepsi cerpen sufistik dibandingkan dengan nilai minat baca.

4. Hasil Pengujian Hipotesis Penguasaan Kosakata dan Minat Baca dengan Kemampuan Meresepsi Cerpen Sufistik

Hasil penghitungan yang dilakukan memperlihatkan adanya korelasi yang signifikan. Penguasaan kosakata dan minat baca dapat digunakan untuk memprediksi kemampuan meresepsi cerpen sufistik. Hal tersebut dibuktikan oleh hasil pengujian korelasi ganda, yaitu $\mathrm{R}$ tabel sebesar 0,349 dengan taraf signifikansi 0,05 dan derajat kebebasan 32; sedangkan nilia uji signifikansi F sebesar 5,0031 lebih besar daripada F tabel sebesar 3,30. Jadi, dapat disimpulkan bahwa :

Ry.x1x2:0,488>rt : 0,349( $: 0,05)$

$\mathrm{Fr}: 5,0013>\mathrm{Ft}: 3,30$

Hasil penelitian tersebut memperlihatkan bahwa semakin baik penguasaan kosakata dan minat baca, maka akan semakin baik kemampuan siswa meresepsi cerpen sufistik.

\section{Simpulan} berikut :

Secara rinci kesimpulan dari hasil penelitian dapat diuraikan sebagai

1. Penguasaan kosakata (X1) mempunyai hubungan positif dengan kemampuan meresepsi cerpen sufistik $(\mathrm{Y})$. Hal ini menunjukkan bahwa jika penguasaan kosakata (X1) ditingkatkan, akan terjadi peningkatan kemampuan meresepsi cerpen sufistik.

2. Minat baca (X2) memiliki hubungan positif dengan kemampuan meresepsi cerpen sufistik (Y). Hal itu menunjukkan bahwa minat baca secara konsisten berhubungan langsung dengan kemampuan meresepsi cerpen sufistik. Hal itu juga berarti bahwa semakin baik minat baca siswa, maka semakin baik pula kemampuan siswa meresepsi cerpen sufistik.

3. Penguasaan kosakata (X1) dan minat baca (X2) secara bersama-sama 
mempunyai hubungan positif dengan kemampuan meresepsi cerpen sufistik (Y). Hal itu berarti bahwa kemampuan meresepsi cerpen sufistik (Y)dapat ditingkatkan melalui peningkatan penguasaan kosakata dan minat baca secara bersama-sama.

Berdasarkan temuan tersebut di atas, secara umum dapat disimpulkan bahwa kemampuan meresepsi cerpen sufistik dapat ditingkatkan melalui peningkatan penguasaan kosakata dan minat baca baik secara sendiri-sendiri maupun secara bersama-sama.

\section{Saran}

Berdasarkan hasil penelitian dan kesimpulan yang telah dipaparkan di atas, maka dapat diajukan beberapa saran sebagai berikut :

1. Untuk meningkatkan kemampuan meresepsi cerpen sufistik, hendaknya guru memotivasi siswa untuk meningkatkan penguasaan kosakata dan minat baca mereka dengan cara menciptakan suasana belajar yang kondusif dan PAIKEM (Pembelajaran Aktif, Inovatif, Kreatif, Efektif dan Menyenangkan).

2. Pihak sekolah perlu menyediakan bahan-bahan bacaan seperti buku-buku yang terkait denga kurikulum, buku-buku agama, majalah-majalah islami, buku-buku bahasa dan sastra Indonesia di perpustakaan. Bahan-bahan bacaan tersebut dapat memotivasi minat baca, memperdalam, dan memperkaya kosa kata dan khasanah keilmuan siswa.

3. Mewajibkan setiap siswa menjadi anggota perpustakaan, baik perpustakaan sekolah maupun perpustakaan umum.

\section{Daftar Pustaka}

David, Mariem. 1994. Woman, Family and Education. New York: Nicols Publising.

Esposito, John L. 1998. Dunia Islam Modern. Jakarta: Mizan.

Nasution, Harun. 1999. Filsafat dan Mistisisme dalam Islam. Jakarta: Bulan Bintang.

Franz, Kurt dan Bernhard Meier. 1996. Membina Minat Baca. Bandung: Remaja Karya.

Suara Merdeka. 6 Oktober 2001“Antara Pro dan Kontra Tasawuf”. Jakarta. 
Tarigan. Hendri Guntur. 1993. Pengajaran Kosakata. Bandung: Angkasa.

Tarigan. Hendri Guntur. 1995. Membaca Sebagai Suatu Ketrampilan Berbahasa. Bandung: Angkasa

Tingkers, Miles A. 1995. Teaching Reading in the Elementary School.New Jersey: Prentice-Hall Inc.

Whiterington, 1995. Psikologi. Jakarta: Aksara

Daftar Laman

http://www.pesantrenonline.com//Tasawuf di Abad Modern.

Klinik Tasawuf http://www.klikdt.com/,syamsu Dharma, Tasawuf sebagai Mazhab cinta.

Suara Merdeka, 6 Oktober 2011 "Antara Pro dan Kontra Tasawuf”, Jakarta 